Current Issues of Education and Science, 2021

DOI: https://doi.org/10.26697/9786177089147.2021.06

\title{
Creative Potential Development in the Structure of the Future Designer Professionalism

\author{
Elena V. KOSTIUCHENKO
} \\ ${ }^{1}$ Kyiv National University of Culture and Arts, Ukraine
}

Corresponding Author Details

Elena V. KOSTIUCHENKO, g2069544@gmail.com

Received: 25.09.2021; Accepted: 22.10.2021; Published: 17.12.2021

\section{Brief Summary}

Background: The problem of the designer's creative personality formation by effective remedies and methods of his affective, personal, social, and cognitive spheres development through his inclusion in artistic and design activity is relevant.

The aim of the study: To determine the development features of the creative potential of the future designers' personalities.

Methods: Analysis, synthesis, systematization, and generalization of theoretical principles on creative activity, conditions for the creative personality formation and creative abilities development, design as a synthesis of technique and art, formation of design education, professional education of future designers.

Results: The creative potential within the framework of the activity approach and its components are defined as a set of properties of a particular character and intensity of interrelation, characterizing the extent of a person's ability to carry out the creative activity. The main features of design and artistic creativity, which make up the designer's professionalism and features of their identification in a professional occupation, are highlighted. The system of methods, techniques for the development of motivational-target, cognitive-content, and reflexive-creative components of the creative potential of future designers is presented. This system is aimed at awareness of the system of images "I (professional)-Others-World"; 
integration of creative and cognitive activities; artistic and figurative modeling; modeling of actual reality; metaphorical modeling of own professional brand, professional purpose, resources of own professional growth, ways of professional self-realization, relations in the professional environment, etc.

Conclusions: The peculiarities of the creative potential development of the future designers' personality in professional training are theoretically analyzed, elements of its comprehensive educational and methodological support on a psychological basis are developed; peculiarities of design and artistic activity, content and structure of designer's professionalism are revealed.

\section{Keywords:}

creative potential, creative potential development, creativity, designer's professionalism components, design and artistic activity.

\section{Background:}

The peculiarities of society's socio-cultural development, a significant number of innovative technologies, increasing the rate of their production and consumption cause toughening requirements for the professional training of various design specialties specialists, which determine the need for innovative approaches to education, updating its content taking into account the creative development of the individual. The problem of forming the designer's creative personality by effective means and methods of his affective, personal, social, and cognitive spheres development, as well as inclusion in artistic and project activities related to creating a harmonious socio-cultural, information and communication, subject-spatial environment, and products that satisfy the material, aesthetic and spiritual needs of a person is relevant.

The aim of the study. To determine the features of the future designers' creative potential development.

\section{Methods:}

The research uses such general scientific theoretical methods as analysis (including retrospective analysis of philosophical, sociopsychological, psychological and pedagogical studies), synthesis, theoretical positions systematization and generalization: about the peculiarities of the realization and development of creative potential, creative strategies and practices, creativity of the individual (Guilford, 1967; Kaplan, 2019; Kaufman \& Sternberg, 2006; Melnyk \& Pypenko, 2017; Moliako, 2007; Richardson \& Mishra, 2018; Torrance, 1962; Urban, 2014); on the formation and realization of the creative personality of the 
designer in professional activities as a synthesis of technology, creativity and art (Berman, 2011; Judkins, 2001; Kalinicheva et al., 2011; Kostiuchenko, 2018; Madjugina \& Tolmacheva, 2017; Meadows, 2009). Analysis of the theory and practice of future designers' professional training makes it possible to confirm the lack of a holistic, systematic and consistent study in psychology and pedagogy of the creative potential development of the specialists' personality in this field.

\section{Results:}

We believe that within the framework of the activity approach, the most productive definition of creative potential is offered as a set of properties of a particular character and the interaction intensity that characterize the degree of individual ability to carry out a creative activity. We take as a basis specific components of Moliako (2007) in the structure of creative potential: motivational (curiosity, desire to create something new, to find and solve problems); emotional (inclinations, setbacks; emotional coloring of individual processes, emotional attitude); intuitionism - the ability to manifest unconscious rapid (sometimes instantaneous) assessments; strong-willed (persistence, systematic work; purposefulness, determination); intellectual (speed in assimilating new information); manifestations of universal intelligence. Accordingly, the development of the creative potential of the designer's personality should be carried out through his involvement in various creative activities, in particular, design and artistic creativity, covering the entire process of work and including artistic activity, artistic mastering of objective complex and multifaceted reality, selecting those sides and manifestations that most forcefully reveal their inner world, worldview, tastes, the artistic position of the designer. Systemic thinking, creative thinking, the art of thinking play a significant role in the designer's activity implementation (Kalinicheva et al., 2011; Madjugina \&Tolmacheva, 2017). It is in design and artistic creativity, the main features of which are: novelty and originality of the activity or its result, artistic product; creative results social significance, enrichment of predecessors experience and progressive nature of the activity, the designer's professionalism is manifested in the author's style, which embodies the depth of author's thought through plastic, accuracy, and movements coherence, ability to interpret, activation of sensorimotor, perceptual, mnemonic, imaginary (in particular, a non-standard vision in the known new possibilities of its functioning, production of an unlimited number of ideas, the flexibility of thinking and behavior, independence), which are closely related to the general orientation of the individual, new 
forms of self-realization and personal creativity with the degree of stability of the propensity of the specialist to certain activities (Kostiuchenko, 2018).

The creative activity of a designer in its essence may not always have outstanding results, but participation in creative activity has a positive effect on the personality through improving the future specialist's qualities as a creative person, emotional immersion, general and aesthetic satisfaction with the activity process and products; understanding the essence of the problem, task, situation; unconscious, intuitive problem solving ("out of logic"); strategic in intellectual behavior (personal ability to produce projects); a variety of solutions; the speed of decisions, estimates, forecasts; the art of finding; to choose (ingenuity).

In the structure of personality professionalism, the designer is distinguished by the following main components: mental component (high level of cognitive activity and interest, speed and accuracy of performing mental operations, due to the stability of attention and RAM, the formation of logical thinking skills and a clear algorithm for action, the richness of the active dictionary, the speed of occurrence and the originality of visual and verbal associations, the expressed attitude to the creative fulfillment of the task, the development of creative thinking and fantasy, the desire to learn); cognitive component (understanding the material, its comprehension, figurative thinking); qualities (empathy, strong-willed qualities of a person's creative attitude to the performed activity, psychological readiness to study and work, awareness of their abilities, criticality, motivation and independence of their assessment); personal artistic and aesthetic experience (value attitude to design as art, artistic and aesthetic knowledge and professional skills that ensure the formation of aesthetic tastes and feelings, aesthetic worldview and views) and the ability to creativity. The arsenal of professional methods of design specialists should be based on the experience of creative art influence, artistic means of self-realization of expressive activity, expression of received and processed information outside, and its transformation following their individual experience.

The development of future designers' creative potential is understood by us as a dynamic non-linear process of their professional and personal transformation from a point of view aimed at mastering professional knowledge, acquiring skills, abilities in the field of human harmonization and substantive reality.

At the Kyiv National University of Culture and Arts, as the part of the discipline study "Psychology of Artistic Creativity", for the development of motivational-target, cognitive-substantive, and reflectivecreative components of the creative potential of future design professionals offer a variety of active methods and techniques based on different levels of 
knowledge, rational-logical, figurative, metaphorical, symbolic, intuitive). In particular, various methods of creative and cognitive activity integration are used to realize creative and adaptive potentials of future designers training in the process of storage and distribution (distribution or interconnection) of information: instrumental (group problem solving, algorithm definition, or set of general rules which observance leads to the invention of an optimal solution) and personal (direct management of their behavior, build self-confidence, self-esteem, contribute to the awareness of endless opportunities for self-improvement in any sphere of life), which involve different types of thinking (creative, intuitive, critical, evaluative, visual, figurative, metaphorical).

The following well-known methods-strategies proved to be expedient: Morphological Analysis, Functional and Physical Design Technique, Algorithm for Inventive Problem Solving, Brainstorming, Synectics, Socratic Method, Mind maps, "CARUS" (strategy for the implementation of combinatorial, reconstructing and universal actions, the search for analogies). In the design and artistic activity the principle of creative combination, reconstruction, and analogization of ideas, images and means is implemented, as a result of which the artistic integrity of the image created in demand and the flexible aesthetic concept of the designer is understood - as a professional assessment combined with the correspondence of the image to aesthetic requirements and creative improvisation. The multidimensionality and multifunctionality of images formed by the designer during his work, appear in the course of active acquisition and processing of information, is a specific alloy of the real object reflection perceived by the subject and the subject's previous experience in perceiving such objects and interaction with them, ie, the revealed structure of the internal reality reflection. The experience of using such a psychological method of developing the creative potential of the individual as modeling and its varieties: systemic, symbolic, spatial, metaphorical, role, self-modeling, has shown its effectiveness in finding optimal solutions, assessing options, vision, objects, objects from different sides. Students were invited to represent the system of images "I", "Idesigner", "Other", "World" by means of: a) artistic modeling, which is based primarily on emotional, subconscious and holistic vision of the final result of creativity, on the principle of "from general to partial", perception comes from the whole to more and more differentiated structures with the obligatory fixation of the new in the object, the situation, the relationship between the perceived external parameters of the design object; b) modeling of actual reality through images-metaphors (Kostyuchenko, 2020) as an effective tool of cognitive-creative process in rapid orientation in changing 
conditions, own adaptability, potentiality, stabilization, solving life and professional problems; c) realization of the dynamic nature of formation and development of own image "I-specialist" through presentation in the form of metaphorical image: own professional brand, professional purpose, resources of own professional growth, ways of own professional selfrealization, relations in professional environment, etc. where the process becomes important perception, ideas about the relevant qualities for the chosen profession, skills and abilities, about their own place in the profession, as well as the accumulation of various information about themselves as a specialist, forming a status-role position, ensures the emergence of the first self-assessment.

\section{Conclusions:}

Theoretical analysis of the future designers' creative potential development in professional training is carried out. The peculiarity of artistic and design activity, content, and structure of a designer's professionalism, which is subject to general laws of personality's creative development, is determined by a combination of several components: mental, cognitive, motivational, personal, creative. It has been found out that in design and artistic activity, the development of the creative potential of the designer's personality occurs through the activation of his creative perception and creative understanding in creative activity, and vice versa, in creative and cognitive activity, a new perception of the object arises for the implementation of creative ideas as a result of internal work mastering emotional-psychological, informational, cultural influence. A comprehensive educational and methodological support for the development of future designers' creative potential has been developed. Using the above methods-strategies for finding creative solutions allows the designer to get a significant number of design-conceptual solutions.

\section{Conflicts of interests:}

The author declares that there is no conflict of interests.

\section{Source of support:}

This research did not receive any outside funding or support.

\section{References}

Berman, D. (2011). Do good design: Kak dizayneryi mogut izmenit mir [Do good design: How designers can change the world]. Simvol-Pljus. https://ua1lib.org/book/2875187/69e5ab [in Russian] 
Guilford, J. P (1967). Creativity: Yesterday, today, tomorrow. Journal of Creative Behavior, 1(1), 3-14. https://doi.org/10.1002/j.21626057.1967.tb00002.x

Judkins, R. (2001). The art of creative thinking. Sceptre. https://docplayer.net/190608094-The-art-of-creative-thinking-byrod-judkins.html

Kalinicheva, M. M., Solodovichenko L. N., \& Chepurova O. B. (2011). Kreativnost i preemstvennost $\mathrm{v}$ otechestvennom dizayne [Creativity and continuity in domestic design]. Vestnik Orenburgskogo gosudarstvennogo universiteta - Bulletin of the Orenburg State University, 9, 9-20. https://cyberleninka.ru/article/n/kreativnost-ipreemstvennost-v-otechestvennom-dizayne [in Russian]

Kaplan, D. E. (2019). Creativity in education: Teaching for creativity development. Psychology, 10(2), 140-147. https://doi.org/10.4236/psych.2019.102012

Kaufman, J., \& Sternberg, R. (2006). The international handbook of creativity. Cambrige University press. https://psycnet.apa.org/doi/10.1017/CBO9780511818240

Kostiuchenko, O. V. (2018). Vizualizovana obiektyvatsiia dyzainerskoho svitospryimannia $\mathrm{v}$ dyzain-produkti [Visualization of the design worldview in the design product is visualized]. Visnyk KNUKIM. Kultura $i$ mystetstvo v suchasnomu sviti - Bulletin of KNUKIM. Culture and Art in the Modern World, 37, 292-303. https://doi.org/10.31866/2410-1176.37.2017.155654 [in Ukrainian]

Kostyuchenko, O. (2020). Recreational potential of metaphorization in mental self-regulation of the students. Mental Health: Global Challenges Journal, 3(2), 28-37. https://doi.org/10.32437/mhgcj.v4i2.78

Madjugina, M. A., \& Tolmacheva, G. V. (2017). Kreativnost i tvorcheskoe myishlenie kak vajnyie sostavlyayuschie professionalnyih kompetentsiy studentov-dizaynerov [Creativity and creative thinking as important components of the professional competencies of design students]. Mejdunarodnyiy jurnal eksperimentalnogo obrazovaniya International Journal of Experiential Education, 7, 32-35. https://expeducation.ru/ru/article/view?id=11718 [in Russian]

Meadows, D. H. (2009). Thinking in systems. Earthscan. https://wtf.tw/ref/meadows.pdf

Melnyk, Yu., \& Pypenko, I. (2017). Innovative potential of modern specialist: The essence and content. In Yu. B. Melnyk (Ed.), Psychological and Pedagogical Problems of Modern Specialist 


\section{Formation}

(pp. 9-16).

ANAGRAM;

KRPOCH.

https://doi.org/10.26697/9789669726094.2017.9

Moliako, V. (2007). Tvorchyi potentsial yak psykholohichna problema [Creative potential as a psychological problem]. Psykholohiia $i$ suspilstvo - Psychology and Society, 4, 6-10. http://dspace.wunu.edu.ua/handle/316497/30250 [in Ukrainian]

Richardson, K., \& Mishra, P. (2018). A learning environment that supports student creativity: Developing SCALE. Thinking Skills and Creativity, 27, 45-54. https://doi.org/10.1016/j.tsc.2017.11.004

Torrance, E. P. (1962). Guiding creative talent. Prentice-Hall, Inc. https://doi.org/10.1037/13134-000

Urban, K. K. (2014). From creativity to responsible createlligence. Gifted Education International, 30(3), 237-247. https://doi.org/10.1177/0261429413485399

\section{Information about the author:}

Kostiuchenko Elena Viktorovna - http://orcid.org/0000-0001-7853-2670; Doctor of Psychological Sciences, Associate Professor, Assistant Professor at the Department of Psychology, Kyiv National University of Culture and Arts, Kyiv, Ukraine.

Research interests: mental health and adaptation, recreational aspects of art and artistic creativity, resource and health-saving technologies, management psychology, psychology artistic work, constituents creative and professional potential of personality, etc.

\section{Cite this article as:}

Kostiuchenko, E. V. (2021). Creative potential development in the structure of the future designer professionalism. In Yu. B. Melnyk, \& L. M. Georgieva (Eds.), Current Issues of Education and Science. 9th International Conference, CIES-2021, Riga, Latvia - Kharkiv, Ukraine, November 10-13, 2021, Conference proceedings (pp. 44-51). KRPOCH. https://doi.org/10.26697/9786177089147.2021.06

\section{Copyright information:}
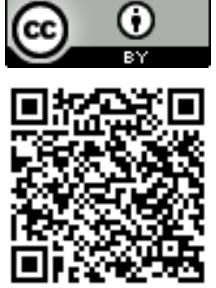

The published paper are licensed under a Creative Commons "Attribution" 4.0 Worldwide

The electronic version of this article is complete. Full or partial reproduction of article is allowed, citing to the source, author(s) and DOI. An electronic copy of the Conference proceedings in open access is available via the KRPOCH Publishing website https://publisher.culturehealth.org 